الاحتياجات التدريبية الزراعية للمرشدين الزراعيين ببعض مراكزمحافظة البحيرة فيما يتعلق ببعض الأنثطة

$$
\text { زالإرشادية المرتبطة بحماية البيئة }
$$

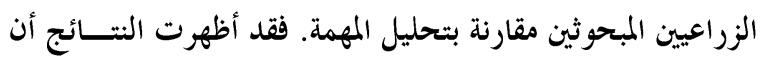

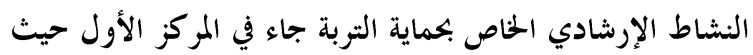

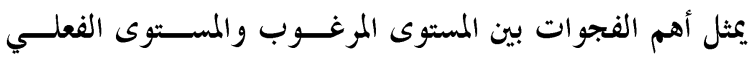

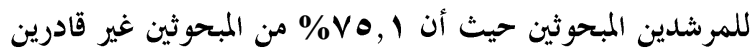

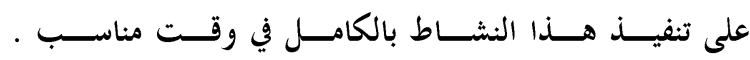
وبالنسبة لتحليل الفجوة للألنطة الإرشادية الفرعية الحاصة بحماية

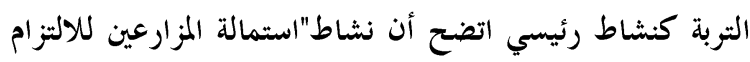

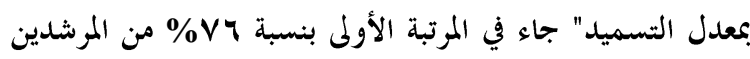

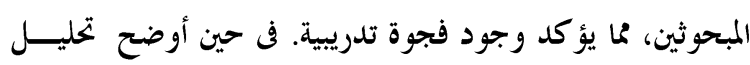

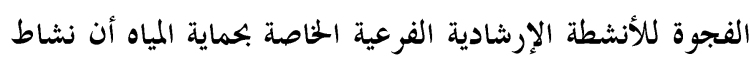

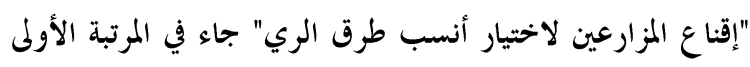

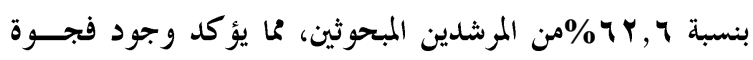

$$
\text { تدريبية . }
$$

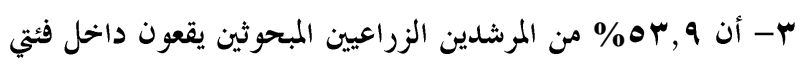

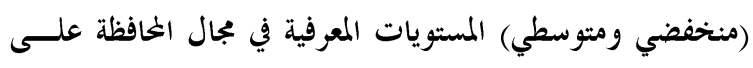
البيئة .

ع-وجود علاقة ارتباطية معنوية بين المستوى المعرف البيئى للمرشدين الزراعيين المبحوثين وكلا من متغيرى المستوى التعليمى والإتجـاه

$$
\text { نحو الخافظة على البيئة . }
$$

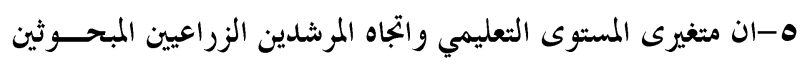

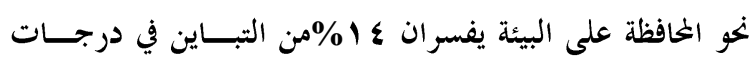

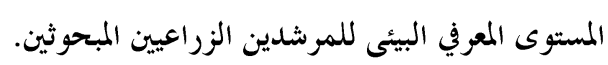

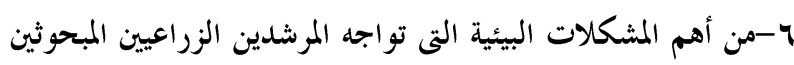

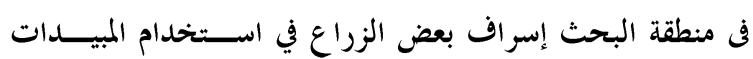

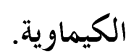

$$
\text { الملخص العربى }
$$

استهدف هذا البحث بصفة رئيسية دراسة الاحتياجات التدريبية

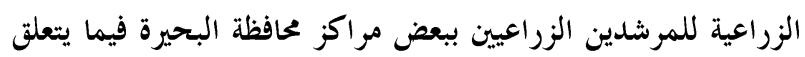
ببعض الأنشطة الإرشادية المرتبطة بحماية البيئة وقد أجرى هذا لئرا البحث

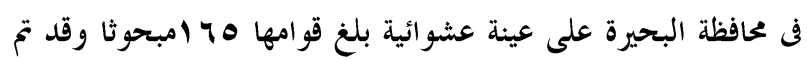
تجميع البيانات عن طريق المقابلة الشخصية للمرشدين الزراعيين

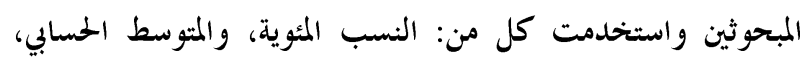
والانخراف المعياري، والمدى، ومعامل الارتباط البسيط لبيرسون،

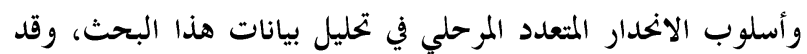

$$
\text { تمثلت أبرز النتائج فل الاتى: الاني: }
$$

1-أسفر تحليل المهمة عن ترتيب الأنشطة الإرشادية الرئيسية المتعلقة

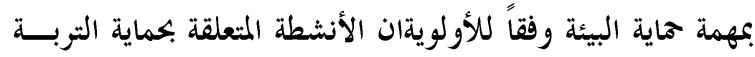
جاءت في المركز الأول يلى ذلك الأنشطة المتعلقة بحمايسة الميــاة

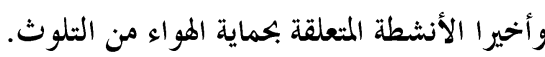

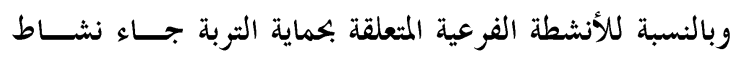

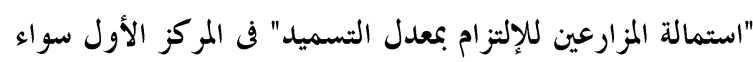

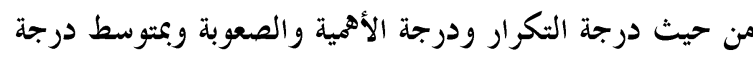

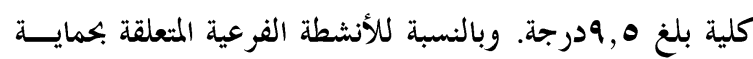

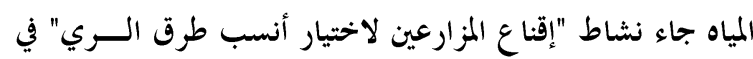

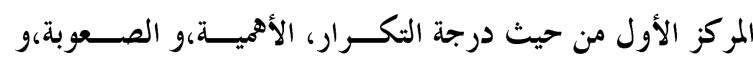

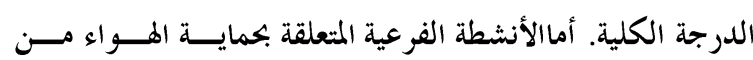

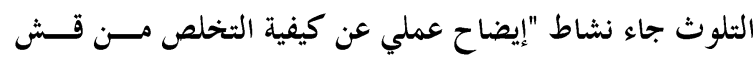

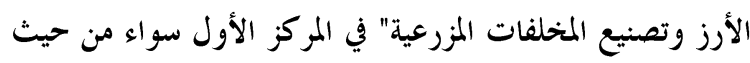
درجة النكرار، و الأهمية، والصعوبة، و الدرجة الكلية. ب-أسفرت نتائج تحليل الفجوة للأنشطة الإرشادية الرئيسية عن عدم

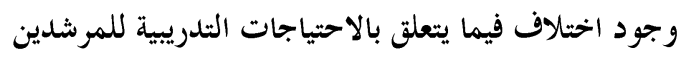


ولقد ترتب على المشكلات البيئة السابقة زيادة حجم الخسائر

الاقتصادية في صورة فقد سنوي في الإنتاج الزراعي القومي نتيجة

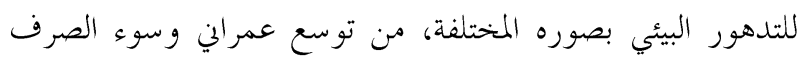

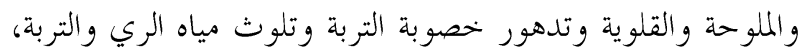

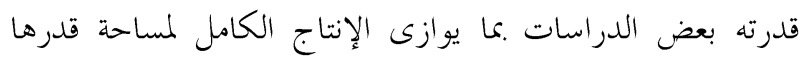

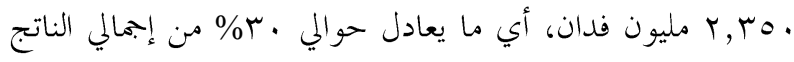

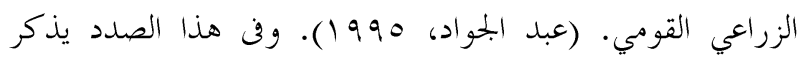

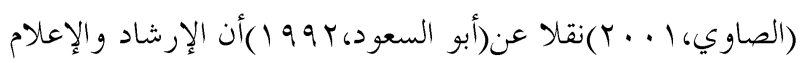

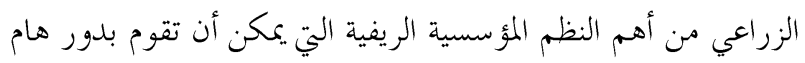

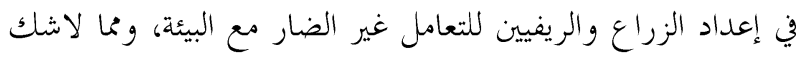

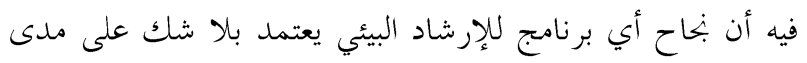

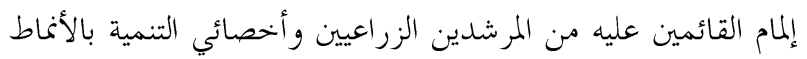

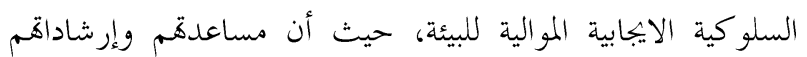
ومشاركتهم في الجهد المستهدف بالتوعية من الزراع يمكن أن تسهم في تحقيق التغيير الايجابي المنشود. و ونظراً لما أظهرته بعض نتائج الدراسات السابقة والتي أجريت في هذا المحال شدة احتياج المرشدين الزراعيين لدورات تدريبية

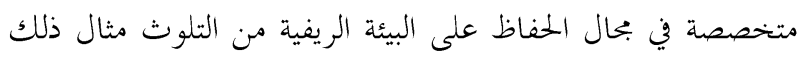
دراسة(عيسوي، لو991)، ودراسة(توفيق، الشناوي، 1991 ()، ودراسة (مدكور، أبو حليمة، ع99 19)ودراسة (الشاذلي، الزرقا،

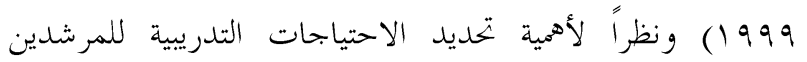
الزراعيين باعتبارها الخطوة الأولى والأساسية في تخطيط أي برنامج تدريي يرفع من كفاءة المرشدين الزراعيين ويهفزهم للعمل في بحال الإرشاد البيئي. لذا فقد أجرى هذا البحث محاولاً الإجابة عن بعض التساؤلات منها: هل مستوى أداء المرشدين الزراعيين في بحال الإرشاد البيئي يتفق مع المستوى المطلوب أداؤه من قبلهم؟وما هي المهام المنوطة كهم

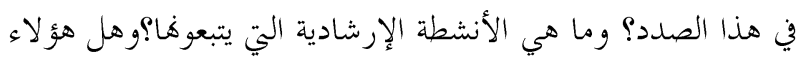
المرشدين في حاجة إلى تدريب مستقبلي لتحسين مستوى أدائهم؟،

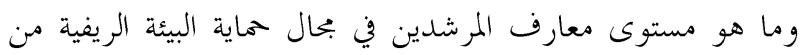

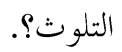

\section{المقدمة و المشكلة البحثية}

تعتبر مشكلة تلوث البيئة إحدى المشاكل التي تواجه الدول

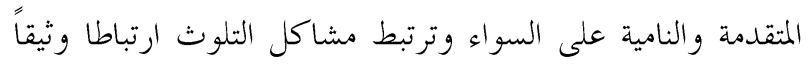

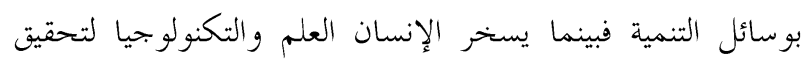
معدلات التنمية التي توفر له الراحة والرفاهية فإنه يواجه مضاعفات لإلهات تلك الرفاهية والتي تتمثل في تلوث البيئة التي قد تعرض حياته للخطر

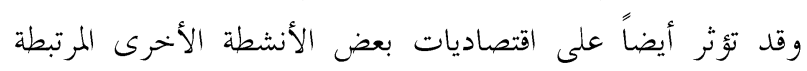
بالتنمية ونغص بالذكر منها القطاع الزراعي. وقد ازداد الاهتمام .مشكلة تلوث البيئة بعد ازدياد مصادر التلوث وتنوعها، وتكشف الآثار الناجمة عن التلوث على صحة

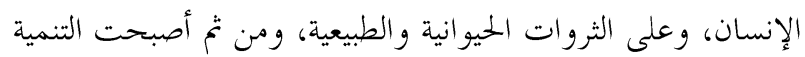

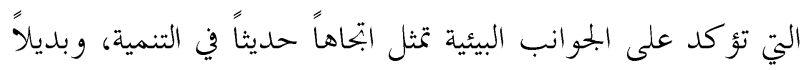

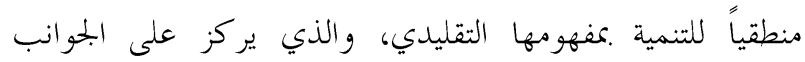
الاقتصادية دون الأخذ في الاعتبار الجوانب البيئية،وحاجات

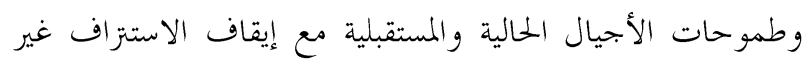
الرشيد للموارد الطبيعية المتجددة أو غير المتجددة.

وتشير بعض الأبحاث أن حوالي . .. مليون مترمكعب/سنة

بنسبة V॰\% من المخلفات السائلة المنصرفة من المصانع بتد طريقها إلى النيل والترع هذا بجانب مياه الصرف الزراعي والتي تقوم وزارة الري بخلط المليارمترمكعب/سنة مع مياه هر النيل لري الأراضي الزراعية، ويضاف إلى ذلك حوالي ه, همليارمترمكعب/سنة من مياه الصرف الصحي تصرف مباشرة في البمارى المائية، مما نتج عنه تراكم هذه الملوثات في التربة الزراعية، وساهم ذلك في تدهور خصوبتها،

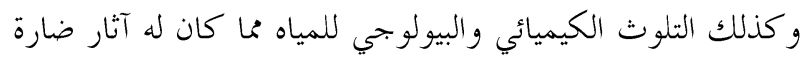
على الإنسان والحيوان، كما تسببت مصانع الطوب الأحمر في

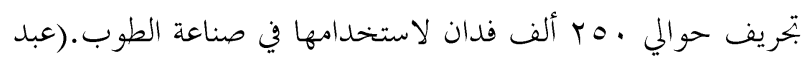
الجواد، 1990 ( الجندي وآخرون، 997 (1).

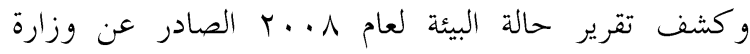

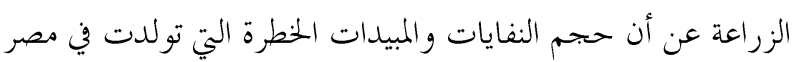
زاد بشكل ملحوظ، إذ بلغ نحو . . عألف طن، أما المبيدات منتهية

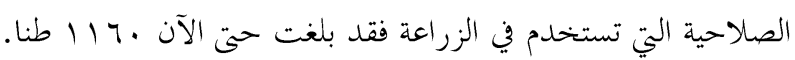

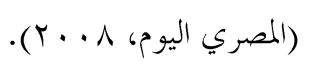


و اهتماماهم في الاتحاه المرغوب فيه لصالح الفرد و المنظمة والمتمع. بينما يذكر (توفيق، 9991) أن التدريب هو تزويد المتدربين

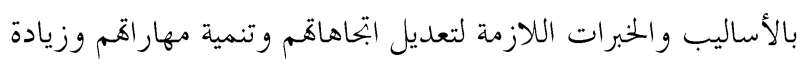
معارفهم من خلال بحموعة من الأدوار التي يؤديها القائمون بالعملية

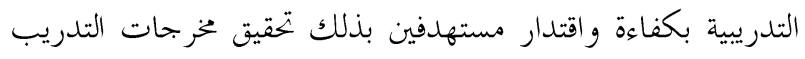
و التنمية المحددة مسبقاً. ويؤيد(هلال، (. . ب) ذلك، حيث ذكرأن التدريب بجهود

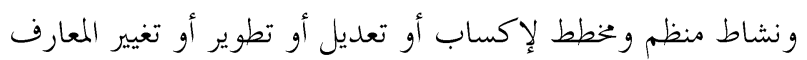

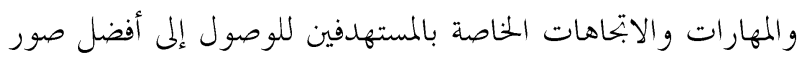
الأداء الإنساني في ظل الأهداف المطلوبة.

مفهوم الاحتياجات التدريبية Training Needs Concept تجدر الإشارة قبل التعرض لمفهوم الاحتياجات التدريبية أن نتعرض لمراحل بناء البرامج التدريبية والتي ذكرها (أبو السعوده،

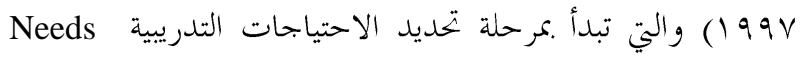

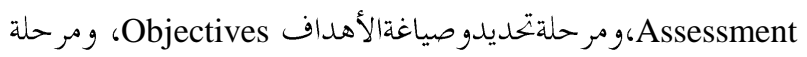
Subject تحديد عناصر وموضوعات المتوى الفني وكتابتها

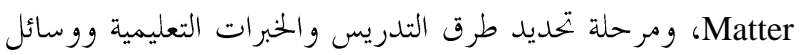
الإيضاح، ومرحلة التنفيذ Implementation، والمرحلة الأخيرة التقييم Evaluation، وتعتبر عملية تحديد الاحتياجات التدريبية القلب النابض للتدريب وأهم مرحلة من مراحل عملية تخطيط

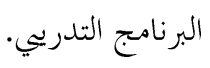

ويعرف (المعهد الدولي للتنمية الإدارية، ب991 (الإحتياجات التدريبية بأها الفجوة بين مستوى الأداء الحالي ومستوى الأداء

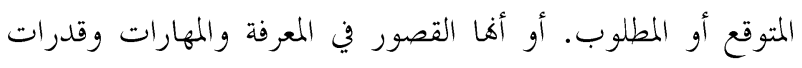
الأفراد و التي تمنعهم من مقابلة متطلبات الحد الأدنى للأداء، حيث

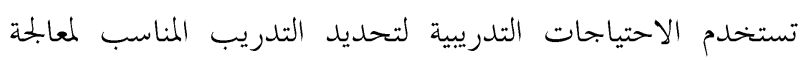

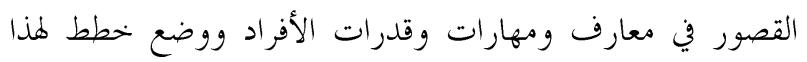

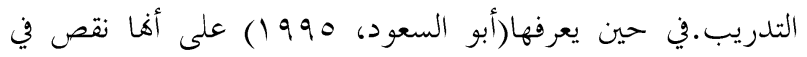

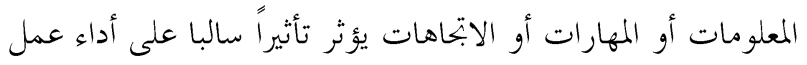
معين أو بلو غ أهداف تنظيم ما.

\section{الأهداف البحثية}

يستهدف هذا البحث بصفة رئيسية دراسة الاحتياجات

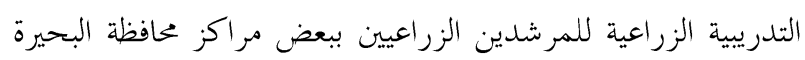

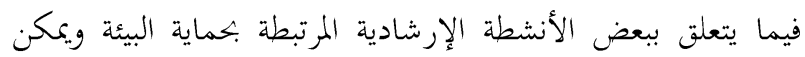
تحقيق هذا الهدف الرئيسي من خلال الأهداف الفرعية التالية:

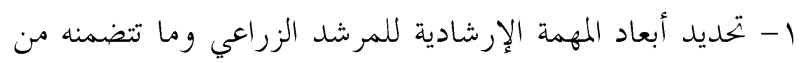
أنشطة إرشادية في بحال حماية البيئة.

r- تحديد الفجوات بين المستوى الحالي لأداء المرشدين المبحوثين

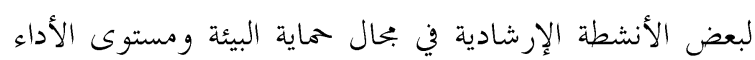

$$
\text { المفترض تو افره بين المرشدين المبحوثين. }
$$

r- دراسة بعض الخصائص العامة المميزة للمرشدين الزراعيين

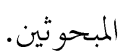

ع - دراسة مستوى المعارف البيئية للمرشدين الزراعيين المبحوثين. ه- تحديد العلاقات الارتباطية والانحدارية بين المستوى المعريف للمرشدين الزراعيين المبحوثين في بحال المحافظة على البيئة كمتغير تابع وكل من الخصائص المميزة للمبحوثين كمتغيرات

\section{مستقلة.}

7- التعرف على بعض المشكلات البيئة التي تواجه المرشدين الزراعيين المبحوثين في منطقة البحث ومقترحاتم لإيباد حلول

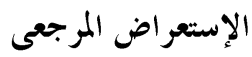

أولا: الإطار النظرى

\section{مغهوم التدريب Training Concept}

أن التدريب يعد من أهم العناصر الأساسية اللازمة لتحقيق

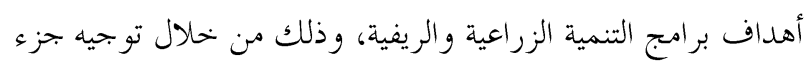
كبير من الاستثمارات نهو الاستثمار في العنصر البشرى لتنمية

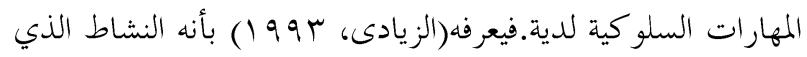
يبذل هدف تزويد المتدربين بالمعارف والمهارات اللازمة لتنميتهم وصقل خبراتم لرفع مستوى الاداء ولتغيير سلو كهم وابتاهاهم 
ENVIRONMENTAL مفهوم التلوث البيئي

:POLLUTION

كلمة التلوث في مفهومها اللغوي بالمعنيين المادي والمعنوي يعنى فساد الشيء سواء كان هذا الشيء كائنا حيا كالإنسان أو الحيوان أو جسما غير حي كالهواء والماء والتربة.

فالتلوث يعنى ببساطه اختلاف مكونات النظام البيئي، ووجود

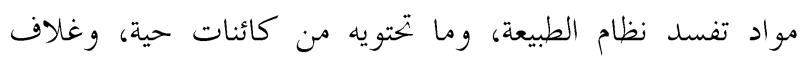

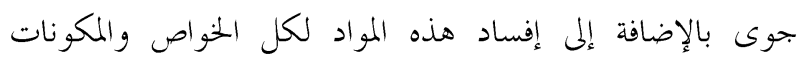

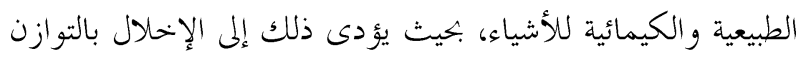

$$
\text { البيئي.(عيسى، . . . (†). }
$$

ويمكن تناول كل من صور تلوث عناصر البيئة عامة مع التركيز

$$
\text { على البيئة الريفية خاصة على النحو التالي: }
$$

- تلوث المياه: تشير (WHO, 1980) إلى أن تلوث المياه هو عبارة عن أي تغيير يطرأ على العناصر الداخلة في تركيبة بطريقة

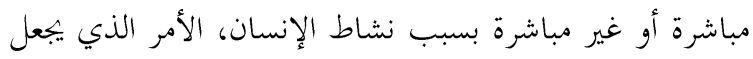

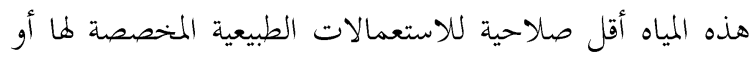

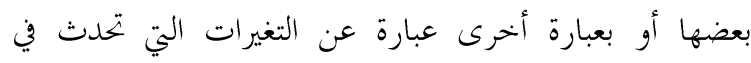

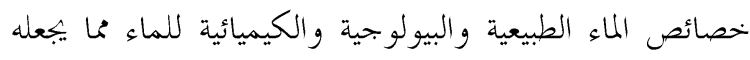
غير صالح للشرب أو الاستعمالات المتزلية و الصناعية والزراعية. -تلوث الهواء: ينشأ عن أي غازات أو جزيئات بتركيزات كافية

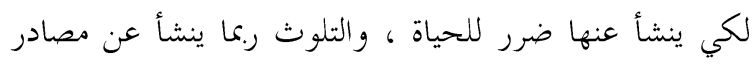

طبيعية أو بيولوجية أو كليهما. (Charles, Mark, 1996). -تلوث التربة: أن مصادر تلوث الأرض والنبات الشديدة التأثير

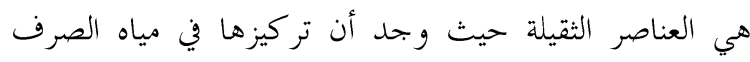
الزراعي أكثر من الحدود الآمنة لها وبنسبة أعلى في التركيز

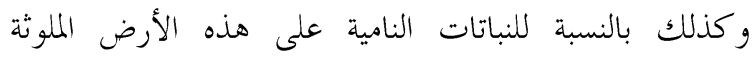
بالعناصر الثقيلة. ويلجا معظم السكان الريفيين إلى الإفراط في

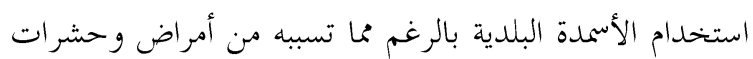
وقوارض وبكتريا وطفيليات، فضلا عن انبعاث الروائح

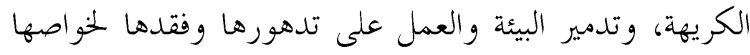

.(Albasel and Cottenie, 1985)
طرق تحديد الاحتياجات التدريبية Needs Assessment Methods إن تحديد الاحتياجات التدريبية يعد عاملاً أساسياً من عوامل بنحاح التدريب فهو الذي يؤدى إلى الاتجاه الصحيح لتنمية القوى

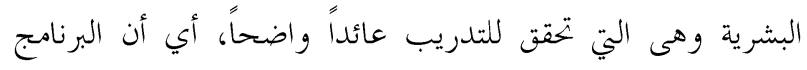
التدريي الذي لا يبنى على أساس قياس علمي للاحتياجات التدريبية

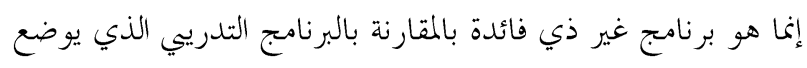
على أساس الاحتياجات التدريبية الفعلية، (الزيادى، (199 ()). يذكر نور( • 19 1) أن تقدير الاحتياجات التدريبية للعاملين في الإرشاد الزراعي يتم من خلال طرق متعددة ترى أن أكثرها تكاملاً تنحصر في:

- 1 ويتضمن هذا النموذج خطوتين، في الأولى يتم حصر المحالات

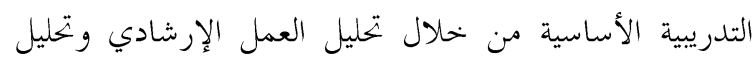

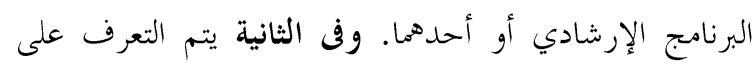

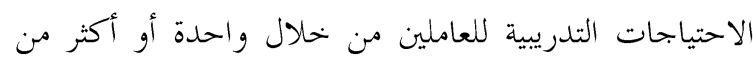

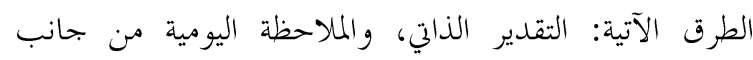
المشرفين، والاختبار ات، وتحليل تقييم الأداء.

Y- نموذج "ماكجيهى، تاير" ويتضمن ثلاث خطوات متكاملة في

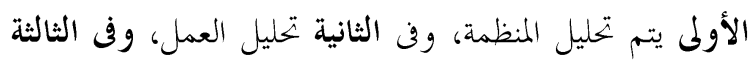

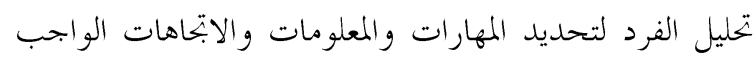
تنميتها لأداء عمله في المنظمة. وتشير (منى صقرع . . ץ) نقلاً عن منظمة الأغذية والزراعة (19191) إلى طريقة لتقدير الاحتياجات التدريبية يتو افر ها مقومات

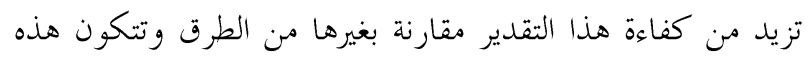

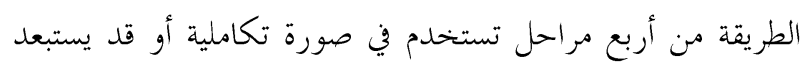

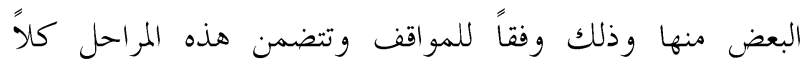

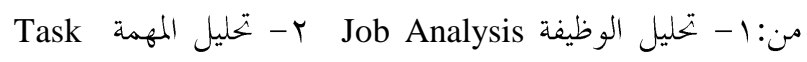
Manalysis المتدربين Determine Trainees Characteristics 


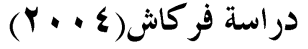

استهدف هذا البحث دراسة السلوك البيئي للمرشدين الزراعيين

ومرتقبات العمل الإرشادي البيئي .منطقة البيضاء بالجماهيرية العربية

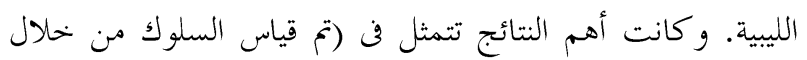

$$
\text { : }
$$

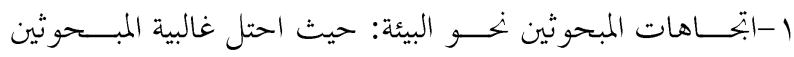

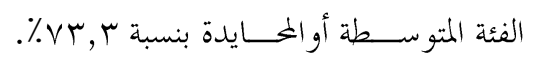

ץ-إدراك المبحوثين لمفهوم البيئة وتلوث عناصرها حيث احتل غالبية

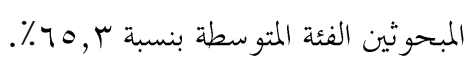

r-اتخاذ القرارات المعنية بالمحافظة وصيانة البيئة: حيث احتل غالبية المبحوثين فئة منخفضة المشاركة في اتخاذ القرارات المعنية

$$
\text { بالمحافظة على البيئة وصيانتها. }
$$

\section{الطريقـــة البحــثـية}

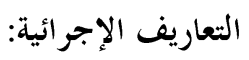

1- الاحتياجات التدريبية: يقصد بها في هذا البحث الفرق بــين

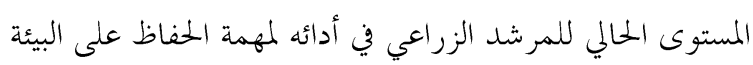

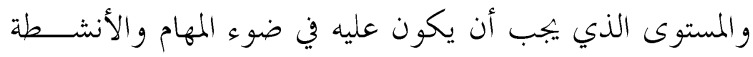

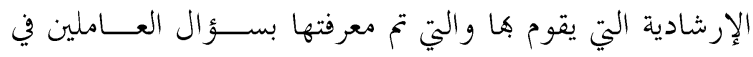

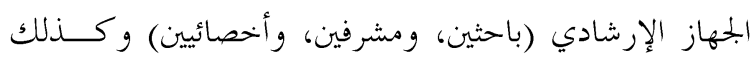
بالرجوع إلى المر اجع العلمية المختلفة في هذا البحال.

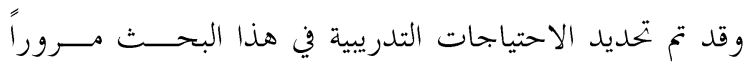

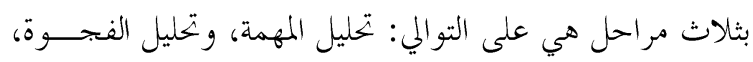
وتحديد خصائص المتدربين. والتي تستند بصــورة رئيسـية إلى

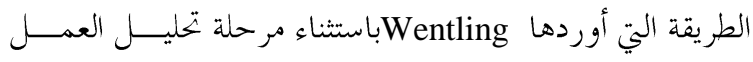
Job Analysis الزراعي (FAO,1992) وقد تم استخدام هذه الطريقة في دراسة

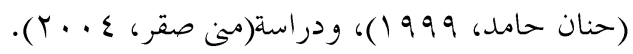

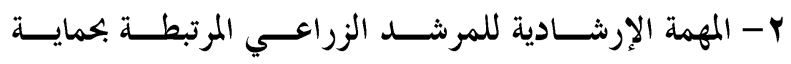
البيئة:يقصد ها في هذا البحث إحدى المهــام الرئيســية الــتي تتضمنها وظيفة المرشد الزراعي في منطقة البحث، والتي تشتمل

$$
\text { بدورها على عديد من الأنشطة. }
$$

ثانيا: بعض الدراسات الإرشادية الزراعية ذات الصلة بموضوع

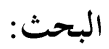
دراسة الشاذلي، والزرقا(ب999 (199): استهدفت الدراسة محاولة تحديد الاحتياجات التدريبية للمرشدين الزراعيين في بحال حماية النظام البيئي في البحتمعات الريفية

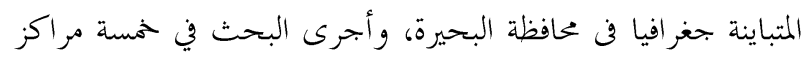
إدارية مكحافظة البحيرة، وجمعت البيانات من خلال استمارة استبيان

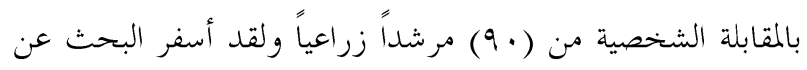

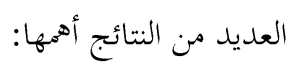
وجود قصورعام في معارف غالبية المرشدين الزراعيين المبحوثين المتعلقة بحماية النظام البيئي، وكان القصور البيئي أكثر لمرئر

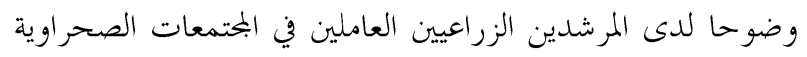

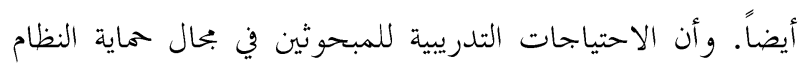

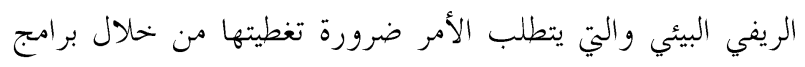
تدريبية مستقبلية سواء ما يتعلق من هذه الاحتياجات ببنود المعارف

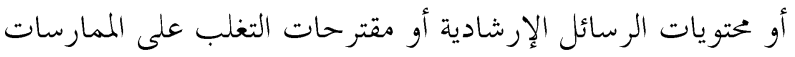

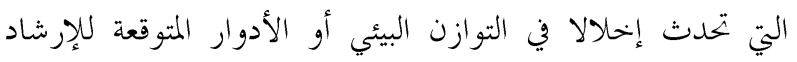
الزراعي في المحافظة على التوازن البيئي.

دراسة عوده، وأخرون (1 (1) استهدف هذا البحث دراسة الاحتياجات التدريبية للمرشدين

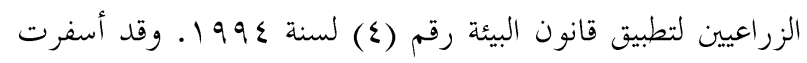
نتائجه عن وجود احتياج معرفي شديد لما يقرب من ثلث لثرين المبحوثين

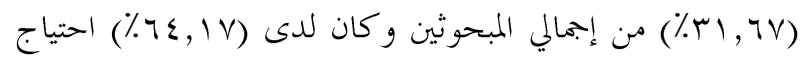
تنفيذي متوسط، وكانت سلوكيات حماية التربة من التدهور، والاستخدام الأمن للمبيدات الحشرية هي أكثر السلوكيات التي

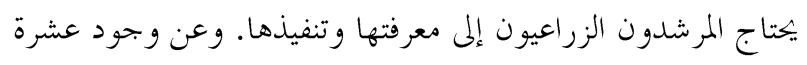

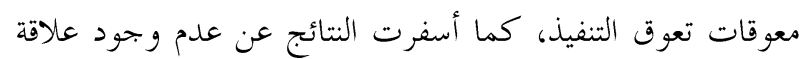
ارتباطيه بين كل من الاحتياج المعرفي والاحتياج التنفيذي وعدم

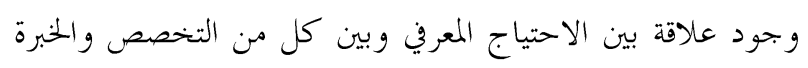

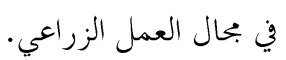


استطيع تنفيذه ولكن في وقت طويل، استطيع تنفيذه في وقــت است

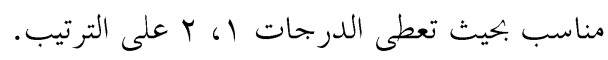

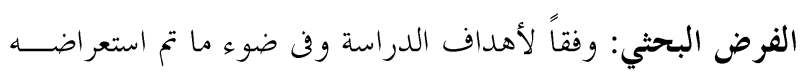

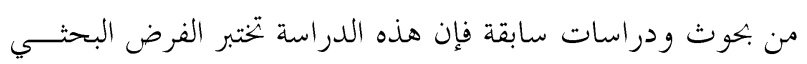
التالي:

توجد علاقة ارتباطيه بين المستوى المعرفي للمرشدين الزراعيين

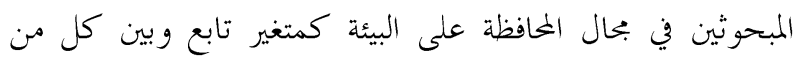

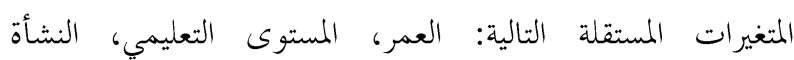

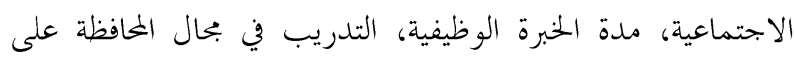

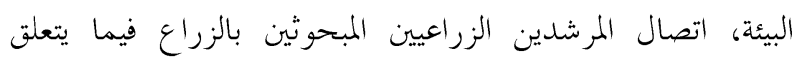

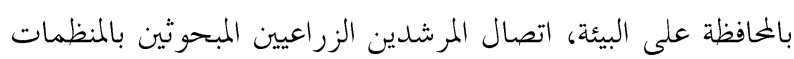

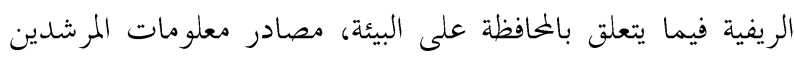
الزراعيين المبحوثين الخناصة بحماية البيئة ومدى الاستفادة منها، استخدام الطرق والوسائل الإرشادية لنقل التوصيات والأفكار

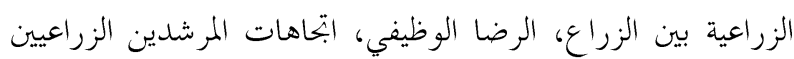

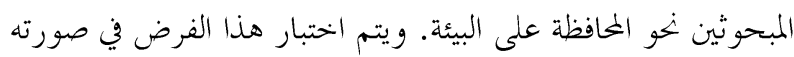
الصفرية التالية: لا توجد علاقة ارتباطيه بين المستوى المعرفي للمرشدين الزراعيين المبحوثين في بحال المحافظة على البيئة كمتغير تابع وبين كل من المتغيرات المستقلة السابق ذكرها كلا على حده.

\section{الشاملة والعينة}

تمثلت شاملة هذا البحث في جميع المرشدين الزراعيين بمحافظة

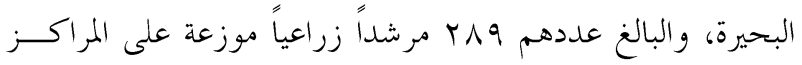

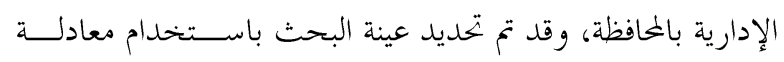
Kregcie \& Morgan زراعياً.

\section{أسلوب بمع البيانات و تحليلها}

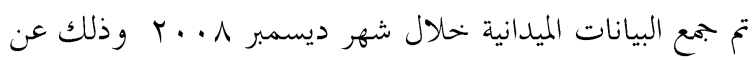
طريق الاستبيان بالمقابلة الشخصية من المرشدين الزراعيين المبحوثين وقد تم تصميم استمارة الاستبيان في ضوء الأهداف البحثية وقد تم

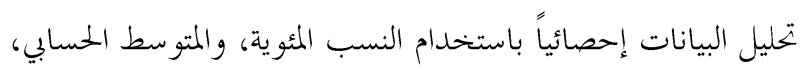
والانحراف المعياري، والمدى، ومعامل الارتباط البسيط لبيرسون،

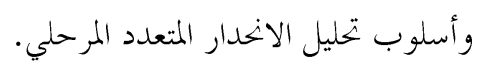

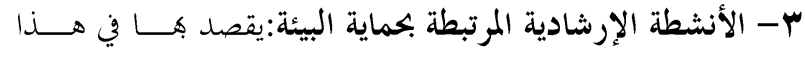

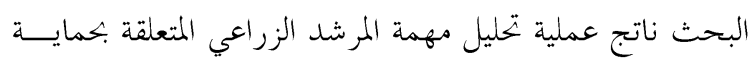

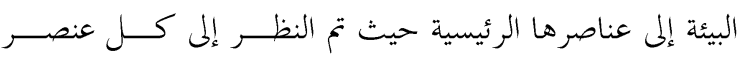

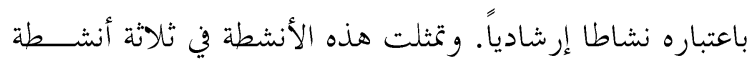

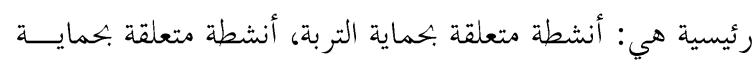
المياة، وأنشطة متعلقة بحماية الهو اء.

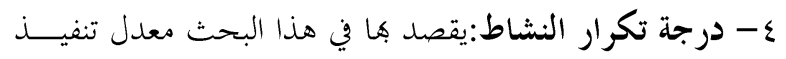

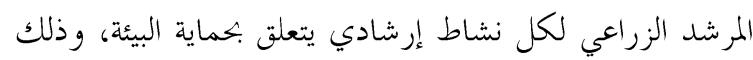

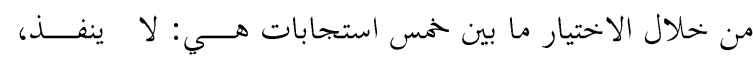

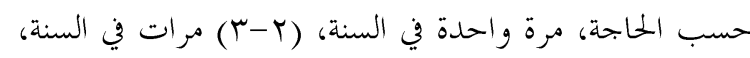

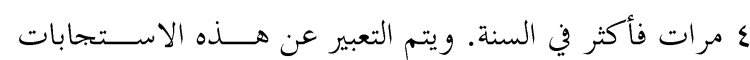

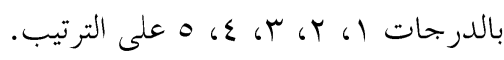

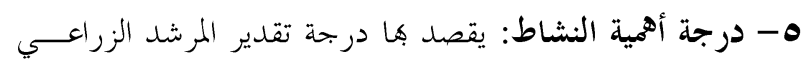

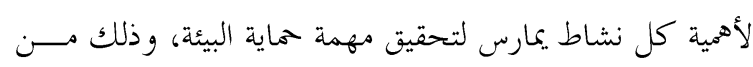

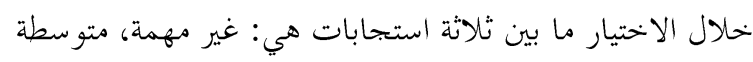

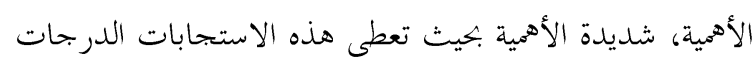

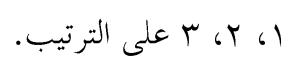

צ- درجة صعوبة النشاط: يقصد ها في هذا البحث التقدير الذاتي

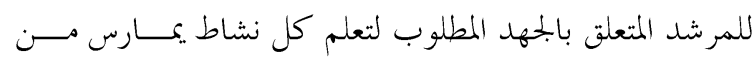

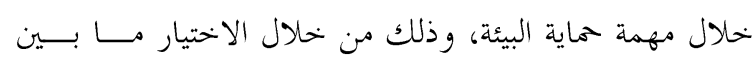

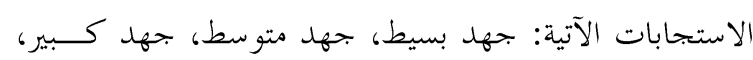

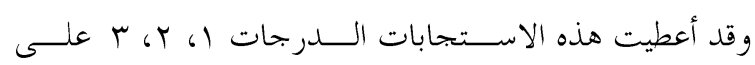
الترتيب.

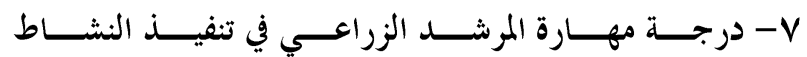

الإرشادي:ويقصد به في هذا البحث وجهة نظر المرشد الزراعي

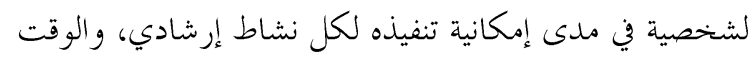

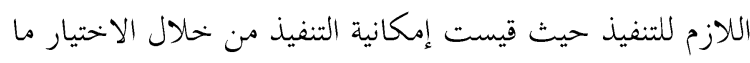
بين أربع استجابات هي: لا استطيع تنفيذه، استطيع تنفيذ جزء

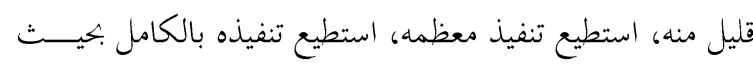

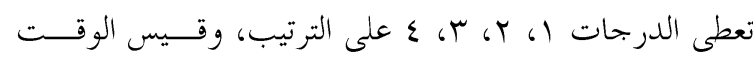

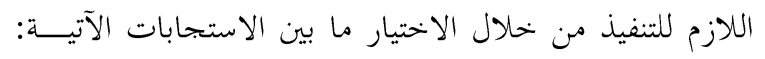


التكرار أو من حيث درجة الأهمية أو من حيث درجة الصعوبة ومتوسط الدرجة الكلية، يلي ذلك في المرتبة الثانية نشاط "إيضاح عملي للمزارعين بكيفية إضافة الأسمدة الكيماوية الملائمة لكل

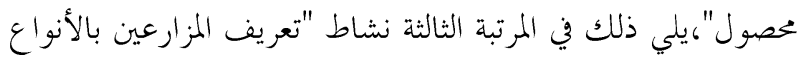

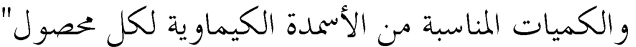

\section{Y - الأنشطة الفرعية المتعلقة بحماية المياه:}

تشير بيانات جدول رقم (؟) إلى ترتيب هذه الأنشطة كالآتي: جاء نشاط "إقناع المزارعين لاختيار أنسب طــــــ الـــري" في

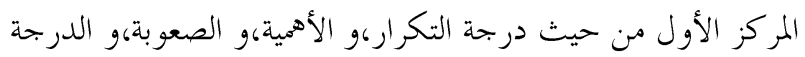
الكلية، يلي ذلك نشاط "إيضاح عملي لبيان الأضر ار الناتجــــة عـــنـ الإسر اف في مياه الري للمحاصيل المختلفة" في المركــــ الثـاني، ثم نشاط "إيضاح عملي عن كيفية تسوية الأرض باستخدام الأساليب

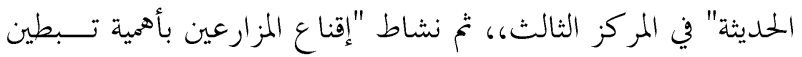

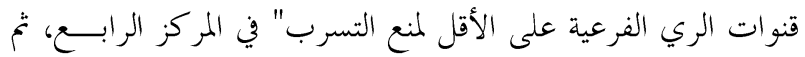

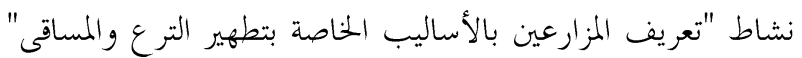

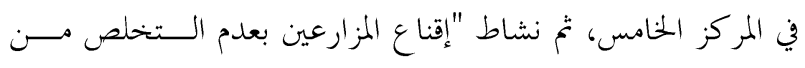
الحيوانات والطيور النافقة وعبوات المبيدات الفارغة برميها في ميــاه

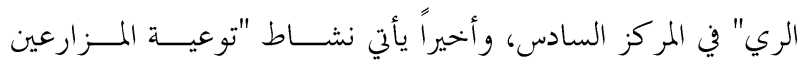
كمخاطر استخدام مياه الصرف الصحي في الري" في المركز السابع. ب- الأنشطة الفرعية المتعلقة بحماية المواء من التلوث: وتوضح بيانات جدول رقم (ع) ترتيب هذه الأنشطة كالتالي: جاء نشاط "إيضاح عملي عن كيفية التخلص من قـش الأرز

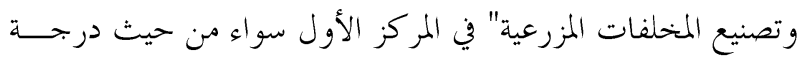

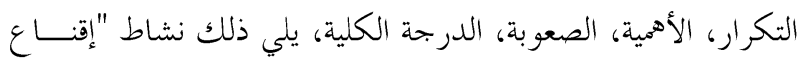

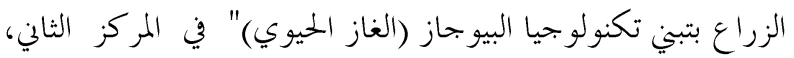

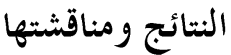

أولا: تحليل مهمة المرشد المتعلقة بحماية البيئة وما تتضــمنه مــن أنشطة إرشادية

تم تحليل المهمة الإرشادية للمرشد الزراعي المتعلقة بحماية البيئسة

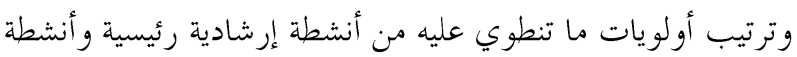

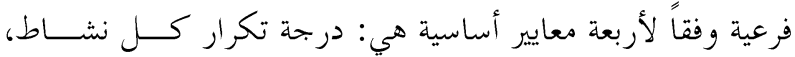
ودرجة أهمية كل نشاط، ودرجة صعوبة تعلم كل نشــاط وكــــا

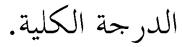
وقد تم تحديد الأنشــطة الرئيسـية والفرعيــة في ضــوء أراء المتخصصين في الجهاز الإرشادي والكتابات المرتبطة هذا الموضوع.

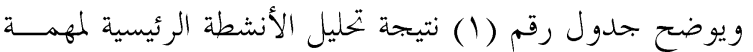
المرشد في حماية البيئة. حيث يلاحظ من الجحدول أن الأنشطة المتعلقة

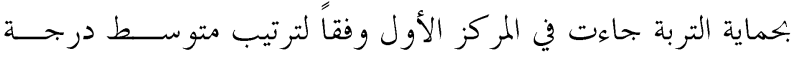
التكرار، الصعوبة والدرجة الكلية، في حين جاءت الأنشطة المتعلقة

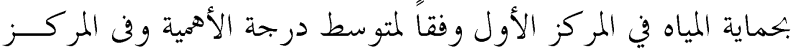

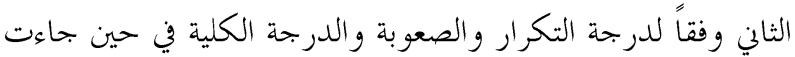

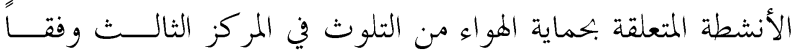

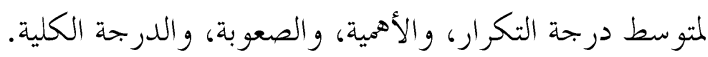
ولمزيد من التدقيق في تحديد الاحتياجات التدريبية للمرشــــين الزراعيين المبحوثين فقد تم تحليل الأنشطة الإرشادية الفرعيــة الـــيتي

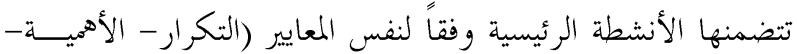
| (الصعوبة- الدرجة الكلية). 1- الأنشطة الفرعية المتعلقة بحماية التربة: كما يتضح من جدول رقم (r) أن نشاط "استمالة المزارعين للالتزام مععدل التسميد" جاء في المركز الأول سواء من حيث دمن درجة

جدول رقم ا ـ تحليل الأنشطة الرئيسية لمهمة المرشد الزراعي في حماية البيئة

\begin{tabular}{|c|c|c|c|c|c|c|c|c|c|}
\hline التركيز & 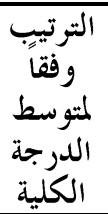 & الدتوسة & المتوسط الترقب & متوسة & 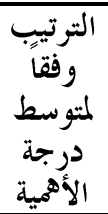 & متوسة & 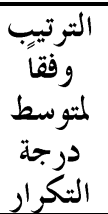 & متوجة & الأنشطة الإرشادية \\
\hline نعم & الأول & $\Lambda, r$ & الأول & $r, 0$ & الثاني & $\overline{r, Y}$ & الأول & $r, r$ & 1 - أنشطة متعلقة بحماية التربة \\
\hline نعم & الثاني & $\vee, \wedge$ & الثاني & $r, r$ & الأوز & $r, v$ & الثاني & $r, \wedge$ & r- أنشطة متعلقة بحماية المياه \\
\hline نعم & الثالث & $7, \varepsilon$ & ال الثالث & $r, 1$ & 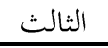 & $r, r$ & الثالث & $r, .0$ & r- أنشطة متعلقة بحماية الهو اء \\
\hline
\end{tabular}




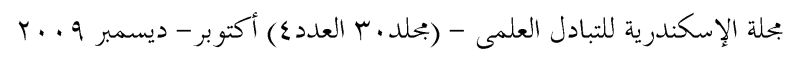




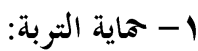

تعكس بيانات جدول رقم (7) الأنشطة الإرشــادية الفرعيــة

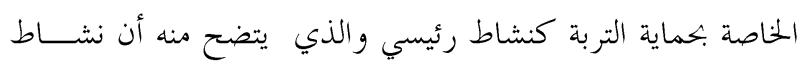

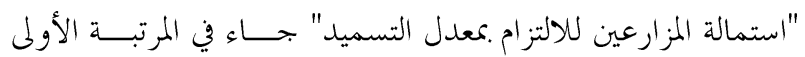

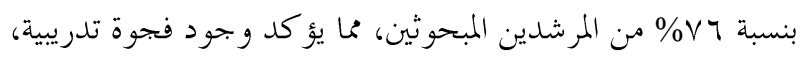

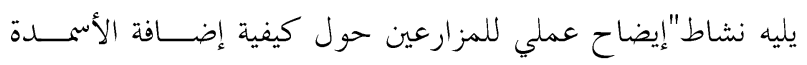

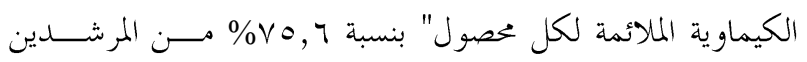

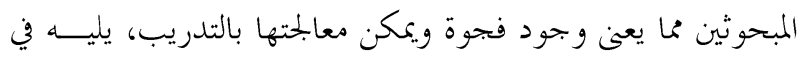

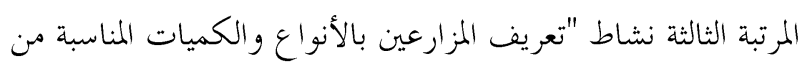

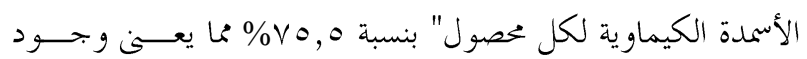
فجوة تدريبية أيضاً. تم يأتي نشاط"إيضاح عملي للمز ارعين بكيفية تحضير واستخدام

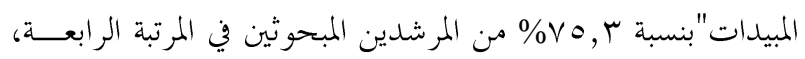

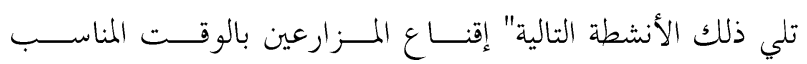

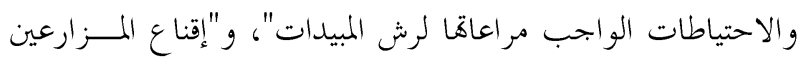

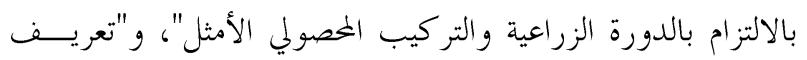

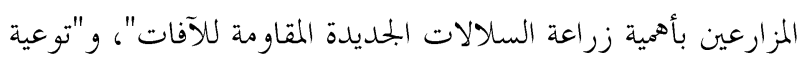

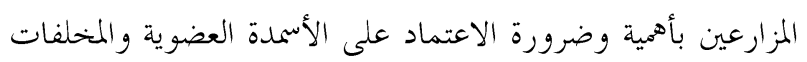

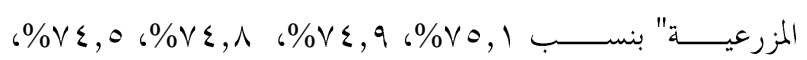

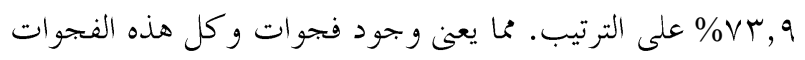

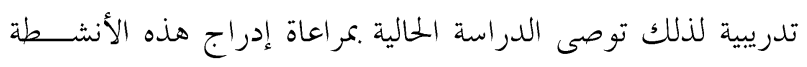
التسعة ضمن محتويات برامج تدريب المرشدين المبحوثين المستقبلية.
يلي ذلك نشاط "توعية الزراع بالأضرار التي قد تنشأ مــن جــــاء

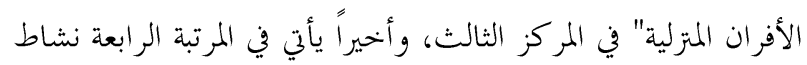

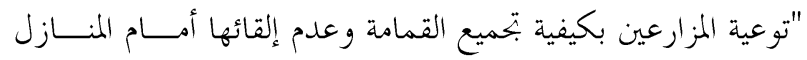

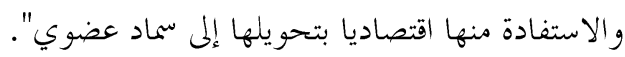
ثانيا: تحليل الفجوة بين مستوى الأداء الحالي والمرغوب للمرشدين الزراعيين المبحوثين

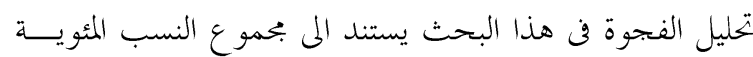

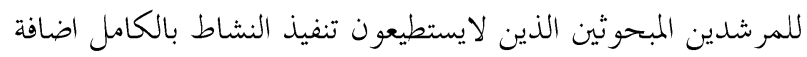

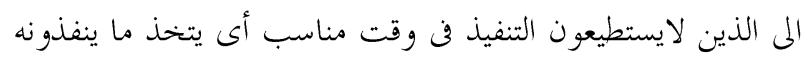
وقتا طويلا يتضح من بيانات جدول رقم (0) أن تحليل الفجوة أسفر عــن

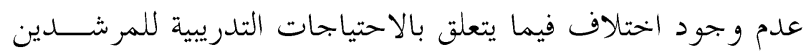

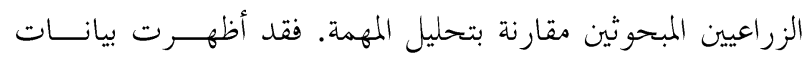

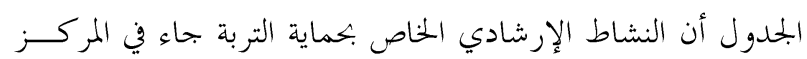

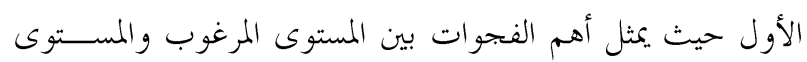

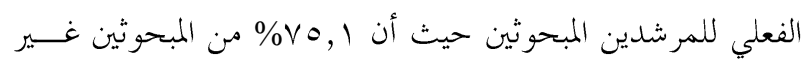

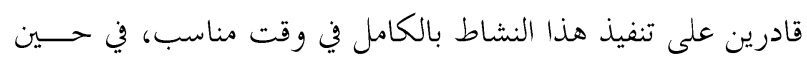

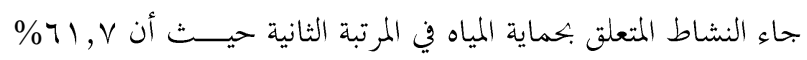

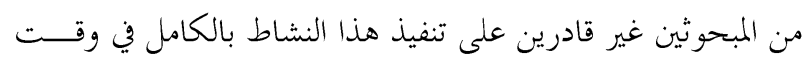

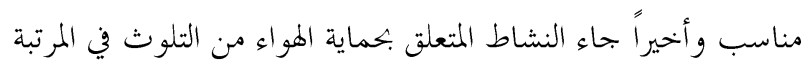

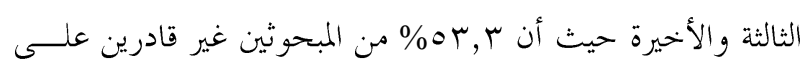
تنفيذ هذا النشاط بالكامل في وقت مناسب.

جدول رقم ه ـ تحليل الفجوة للأنشطة الإرشادية الوئيسية لمهمة حماية البيئة

\begin{tabular}{|c|c|c|c|c|}
\hline 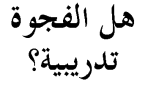 & 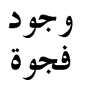 & القدرة الحالية & المستوى المرغوب & الأنثطة الإرشادية \\
\hline نعم & نعم & 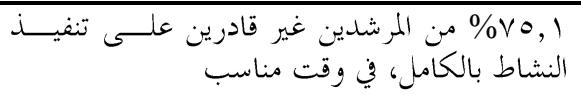 & في وقت مناسب تنفيذ النشاط بالكامل، & 1 - أنشطة حماية التربة \\
\hline نعم & نعم & 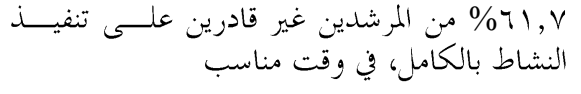 & في وقت مناسب تنفيذ النشاط بالكامل، & ץ- أنشطة حماية المياه \\
\hline نعم & نعم & 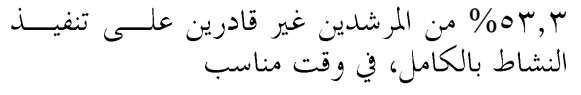 & في وقت مناسب تنفيذ النشاط بالكامل، & با ألنشطة متعلقة بحمايسـة \\
\hline
\end{tabular}




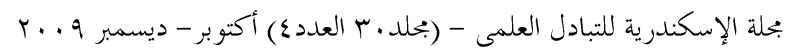


المرتبة الرابعة نشاط "توعية المزارعين بكيفية بحميع القمامة وعـــدم

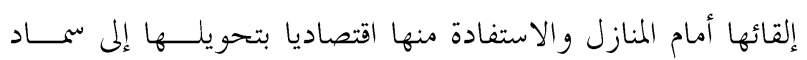
عضوي" بنسبة م, ro\% من المرشدين المبحوثين. ولذلك فان الدراسة الحمالية توصى بأن تولى بــــامج التــــريب

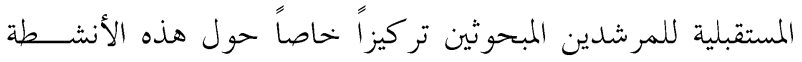
المتعلقة بحماية الهواء.

\section{ثالثا: بعض الخصائص المميزة للمرشدين الزراعيين المبحوثين:}

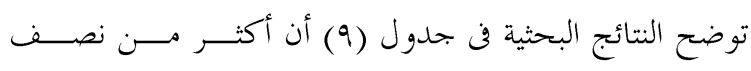

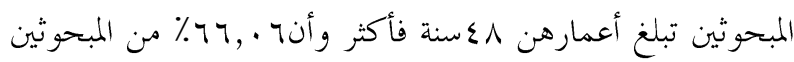

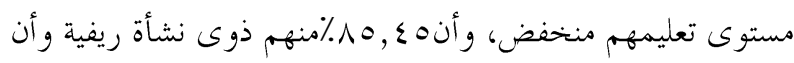

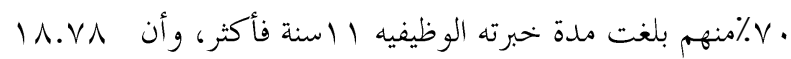

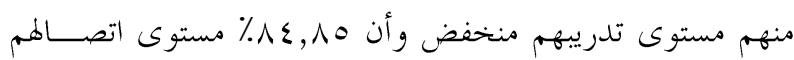

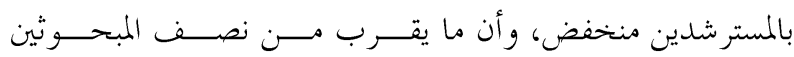

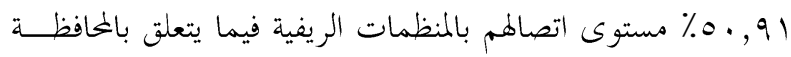

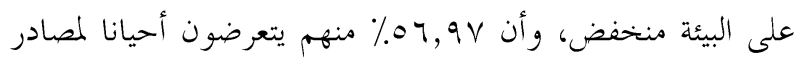
المعلومات، وأن ـ ج ٪ من المبحوثين مستوى قدرهم على اســتخدام

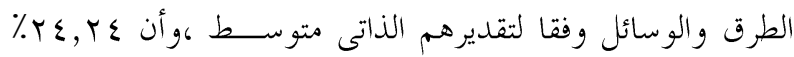

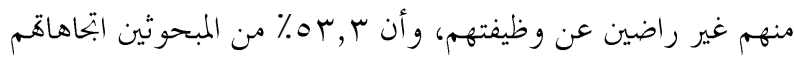

$$
\text { سلبية نو المحافظة على البيئة. }
$$

رابعا: مستوى المعارف البيئية للمرشدين الزراعيين المبحوثين تم قياس المستوى المعرفي للمرشدين الزراعيين المبحوثين في بحال

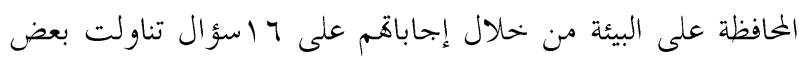

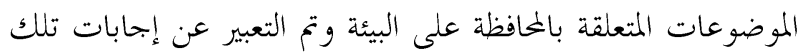

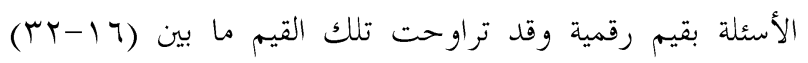

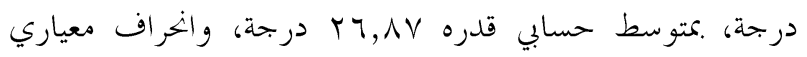

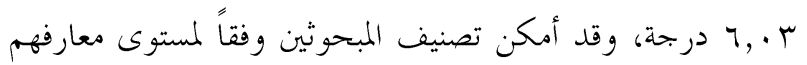

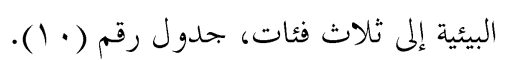

يتضح من جدول (• (1) أن و,به\% من المرشدين الزراعيين المبحوثين ذوى مستوى معرفي منخفض ومتوسط منا يعكس حاجة المرشدين للتدريب الأمر الذي يتطلب وضع برامج وأنشطة إرشادية لتنمية معارف المبحوثين الخاصة بالمحافظة على البيئة.

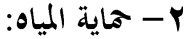

توضح بيانات جدول رقم (V) الأنشطة الإرشــادية الفرعيــة

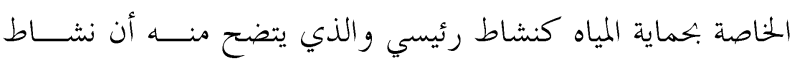

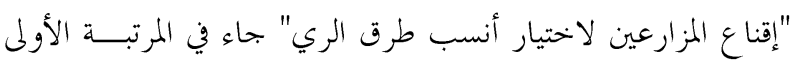

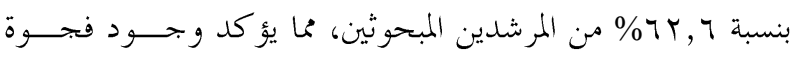

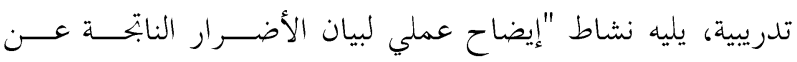

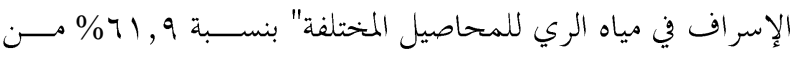
المرشدين المبحوثين، مما يعنى وجود فجوة ويمكن معالجتها بالتدريب،

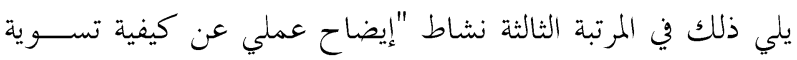

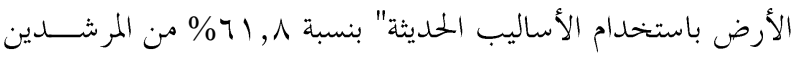

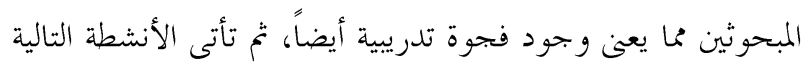

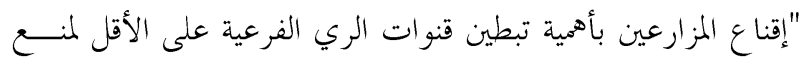

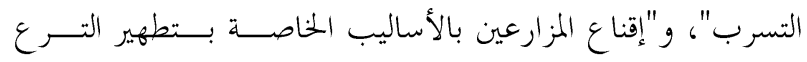

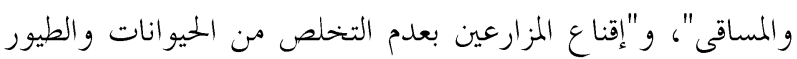

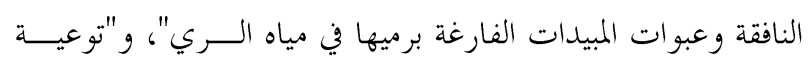

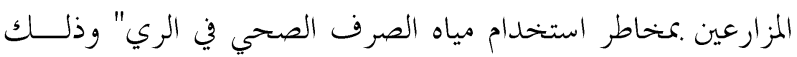

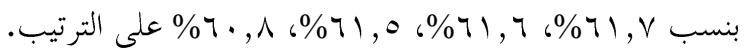

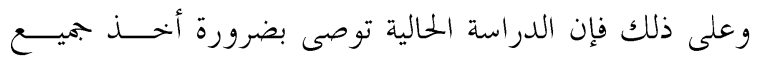

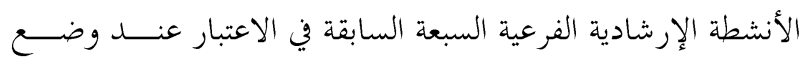

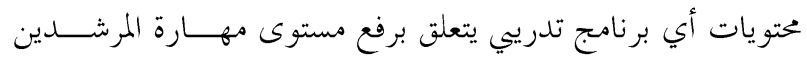
المبحوثين في إبحاز مهمة حماية النظام البيئي.

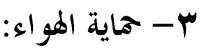

يتضح من بيانات جدول رقم (^) الأنشطة الإرشادية الفرعية

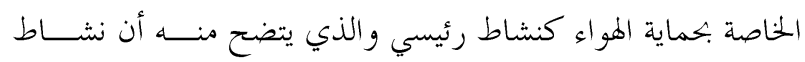

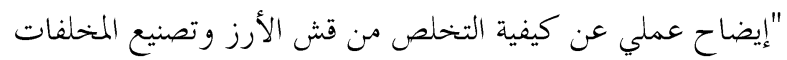

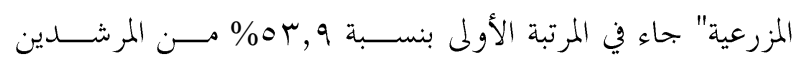

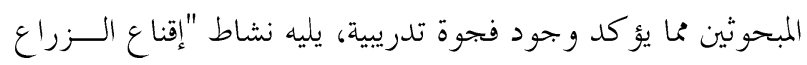
بتبني تكنولوجيا البيوجاز" بنسبة ه,به\% من المرشدين المبحوثين،

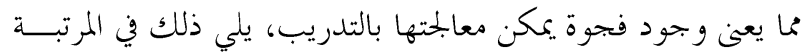

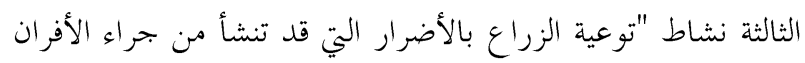

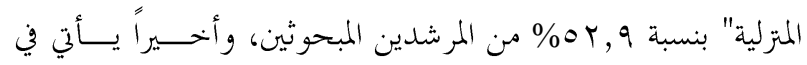


جدول 9.

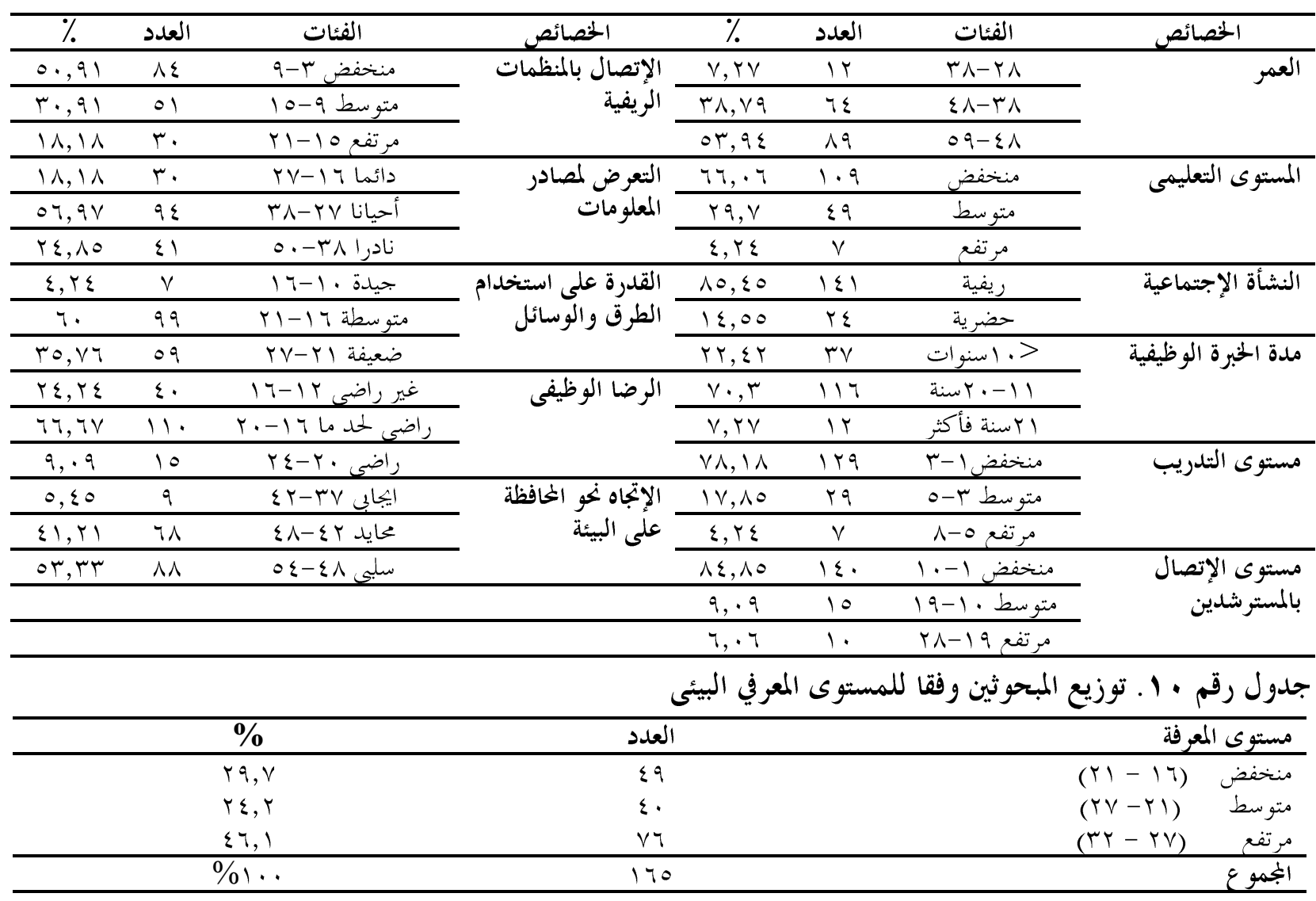

حوالي ع ا\% من التغير في المستوى المعري فلمرشــــين الــزراعيين المبحوثين كمتغير تابع.

سادسا: بعض المشكلات البيئية التي تواجه المرشدين الــزرراعيين

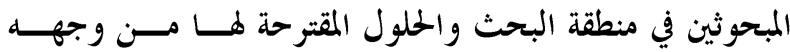

كانت أهم هذه المشكلات الإسراف فن اســتخدام المبيــدات

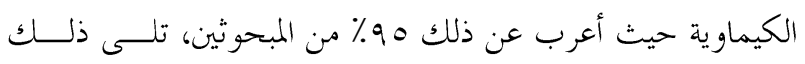

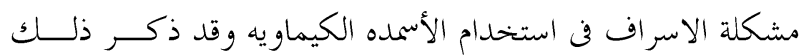

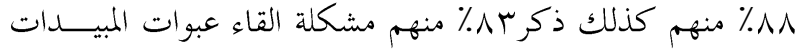

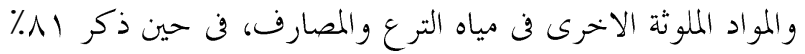

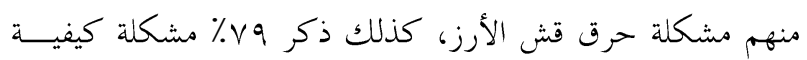
التخلص من المخلفات الزراعية.
خامسا: العلاقات الارتباطية والانحدارية بين المستوى المعرفي البيئى للمرشدين الزراعيين وبعض الخصائص المميزة لهم توضح النتائج البحثية جدول (1) أن من بين عشرة متغيرات

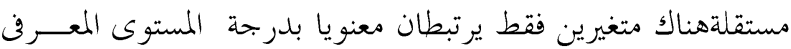
البيئى للمبحوثين وهما المستوى التعليمى للمبحوثين ودرجة ابتحهاتم نهو المحافظة على البيئة جدول رقم (11). مدى التباين فى المستويات المعرفية البيئية للمبحوثين: أوضحت نتائج العلاقات الانحدارية المتعددة معنويـــة التــأثير لمتغيرين مستقلين على المتغير التابع وهما المستوى التعليمى واتجاهات المبحوثين نحو المحافظة على البيئة جدول (r ()). يتضح من الجدول رقم (r ( ) أن قيمة معامل التحديــــ (ر) للمتغيران المستقلان ع ا , .ووالذى يتبين منه أهما مسئو لان عن تفسير 


\section{جدول رقم 11 ا. العلاقات الارتباطية بين المستوى المعرفي البيئى للمبحوثين والمتغيرات المستقلة}

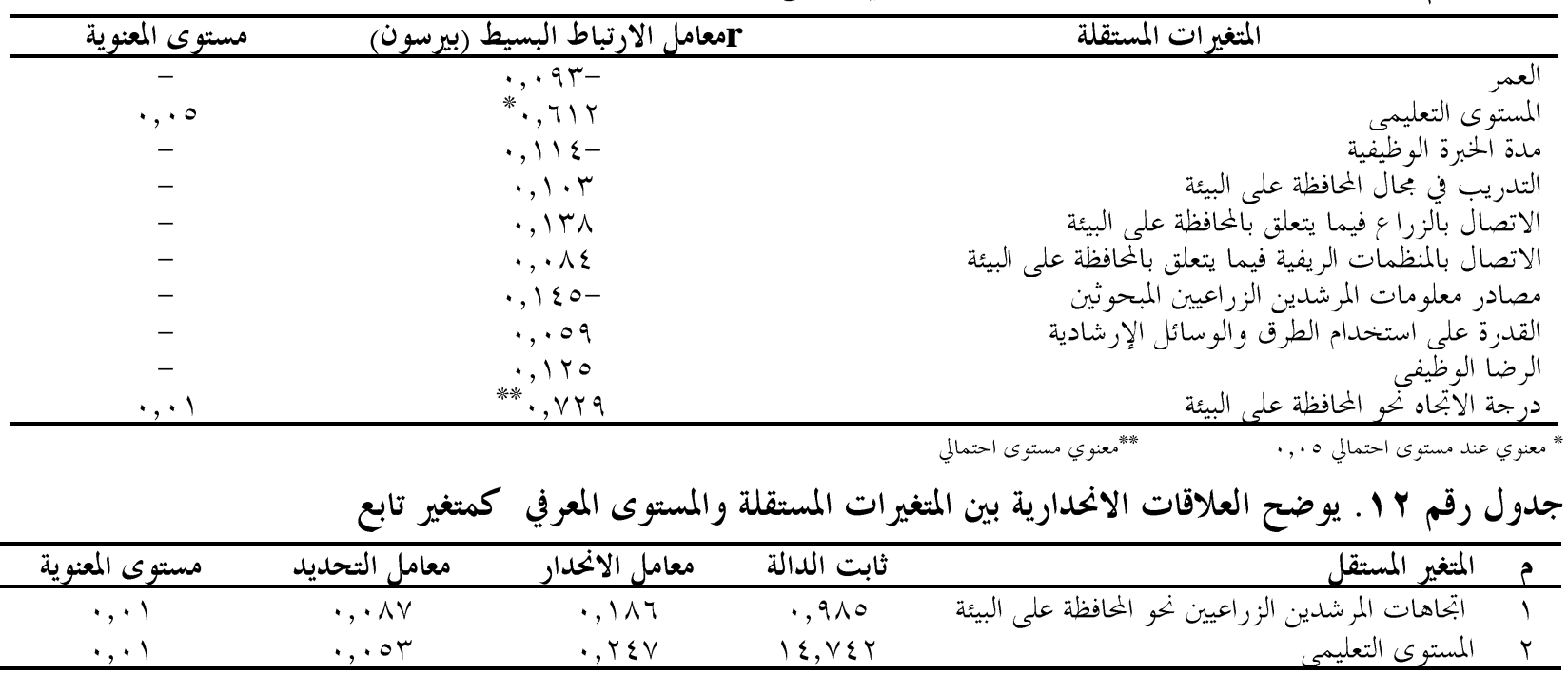

جدول ا I. بعض المشكلات البيئة التي تو اجه المرشدين الزراعيين المبحوثين في منطقة البحث

\begin{tabular}{|c|c|}
\hline تكرار \% & المشكلات \\
\hline 90 & - الإسراف في استخدام المبيدات \\
\hline$\wedge \wedge$ & - الإسر اف في استخدام الأسمدة الكيماوية \\
\hline 人r & - القاء عبوات المبيدات والمواد الملوثة الاخرى في مياه الترع و المصارف \\
\hline$\wedge 1$ & - حرق قش الأرز \\
\hline vq & - كيفية التخلص من المخلفات \\
\hline VT & - تجريف الأرض الزراعية واست \\
\hline 00 & - إلقاء الحيو انات النافقة في التر ع والمصارف \\
\hline
\end{tabular}

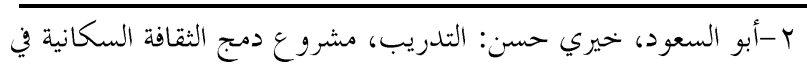

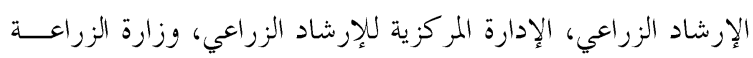

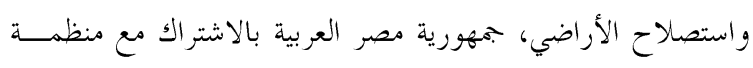

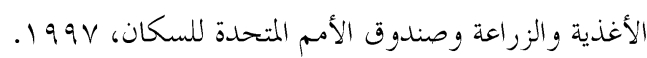

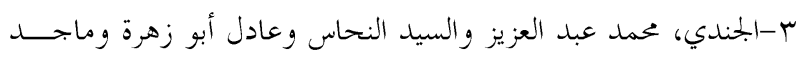

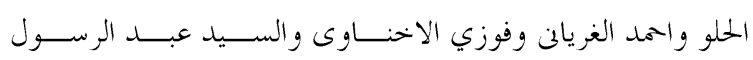

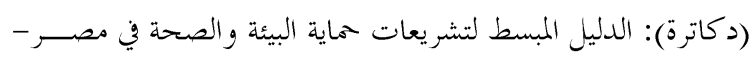

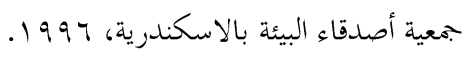

ع -الزيادى، عادل رمضان: التدريب التعاوين ومشكلاته، مكتبة عـــين

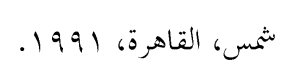

ه-الزيادى، عادل رمضان (دكتور): تدريب الموارد البشرية، مكتبة عين

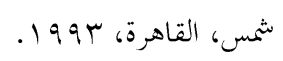

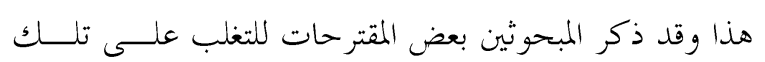

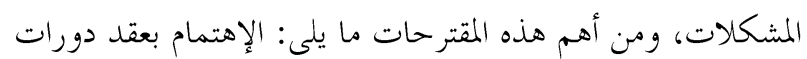

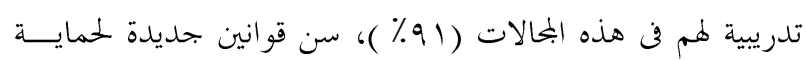
البيئة وتفعيل القائم منها (0 (1\%)، تخصيص أماكن لتجميع المخلفات

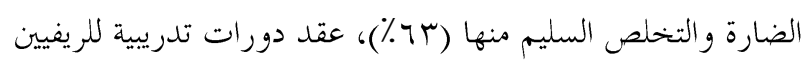

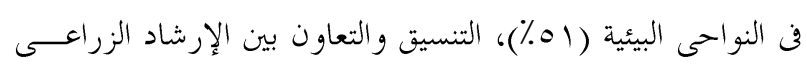

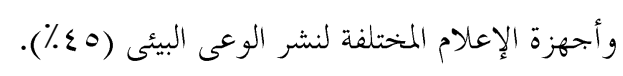

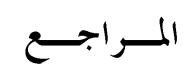

1-أبو السعود، خيري حسن: التدريب التحويلي في ظل التغيرات المتوقعة

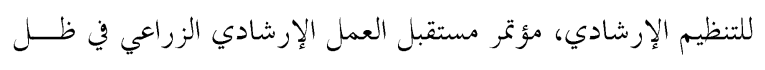

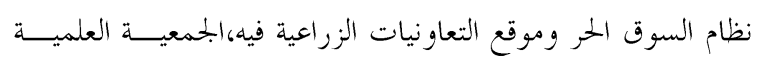

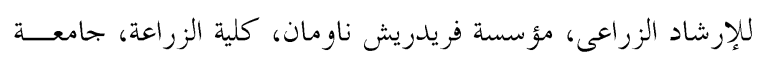

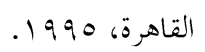




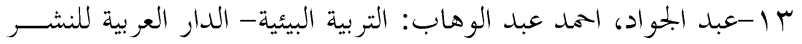

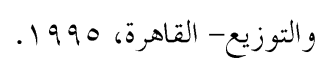

ع ا--عوده، عوده حفني، الدالي، محمد سمير، شادي، سامي على المرسى

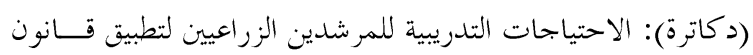

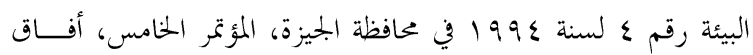
وتحديات الإرشاد الزراعي في بحال البيئة، الجمعية العلمية للإرشـــاد

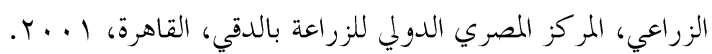
ه - عيسى، إبر اهيم سليمان: تلوث البيئة أهم قضايا العصر، المشــكلة

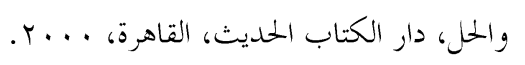

جا (ا- فركاث، محمد ارضيوة: السلوك البيئسي للمرشــــين الــزراعيين ومرتقبات العمل الإرشادي البيئي بمنطقة البيضاء بالجماهيرية العربية

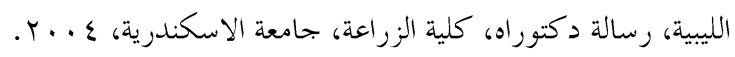
V ا - نور، يوسف محمد : دراسة لتحديد الإحتياجات التدريبية للتدريب أثناء الخدمة للمرشدين الزراعيين في جهمورية مصر العربية ،رســالة ماجستير ، كلية الزراعة ، جامعة القاهرة ، . 19 1 . 1 1 - هلال، محمد عبد الغنى: التدريب الأسس والمبادئ، الطبعة الأولى، موسوعة التدريب، مهارات تطوير الأداء التدريي (1)، مركز تطوير

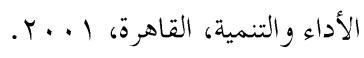

1- Albasel, N. and Cottenie, A.: Heavy Metal contamination near major high ways industrial and urban areas in Belgian Grassland 1995.

2- FAO, Planning for Effective Training: Aguide to curriculum development, Rome, 1992.

3- WHO, Environmental Health; Criteria For noise, Genera, Switzerland,

1980 .
ج-الشاذلي، محمد فتحي، الزرقا، زكريا محمد (دكاترة): الاحتياجـــات

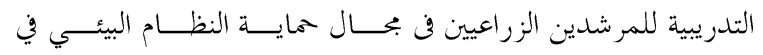

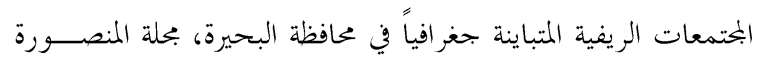

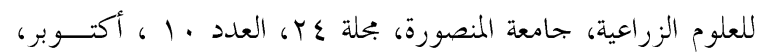

.1999

V-الصاوي، الصاوي محمد أنور (دكتور): دراسة السلوك البيئي للزراع

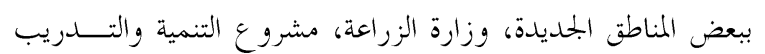

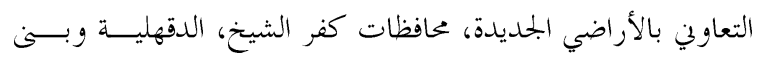

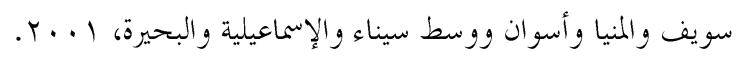

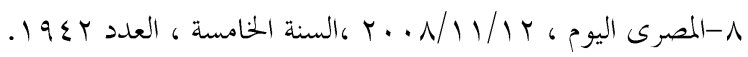
9-المعهد الدولي للتنمية الزراعية والإدارية: إعداد وتقييم برامج التدريب،

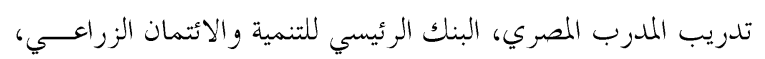
كلية الدراسات للشئون العامة

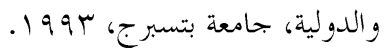

• أ-توفيق، عبد الرحمن: العملية التدريبية، موسوعة التدريب والتنميـــة

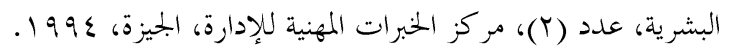

11 للمرشدات الزراعيات بأبعاد تلوث الغذاء في الريف المصري، معهد

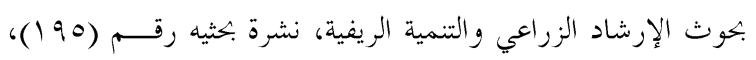
.1991

با -صقر، مني عطية عيد: دراسة الاحتياجات التدريبية الزراعيةالمتعلقـــة بتحسين إنتاجية البطاطس بين العاملين الإرشــاديين الميــــانيين في مركزي كفر الزيات وطنطا بمحافظة الغربية، رسالة ماجستير، كلية

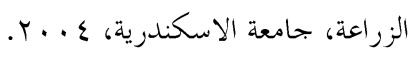




\title{
ABSTRACT \\ Agricultural Training Needs Among Extension Workers in Some Districts in Beheira Governorate Related to Some Environment Extension Activities
}

\author{
Z.M.El-Zarka, A.A.Fayed
}

This research aims mainly at studying agricultural needs among extension workers in some districts in Beheira governorate related to some environment extension activities. A random sample consisted of 165 respondants was slected and the research data were collected through personal interview questionnaire prepared for this purpose. Several statistical methods were used in analyzing and presenting data such as: percentages, repeating tables, simple correlation, and regression analysis .

The most important findings are as follows:

1- Task analysis results: The descending order of extension activities according to the priority of implementation shown by task analysis are related to the follows: soil protection, water protection , air protection against pollution.

In general, the extension activities included: communicate information; demonstration and problem solving.

2- Gap analysis result: The result showed that the gaps between the present and supposed extension agents are related to the same order of extension activities in task analysis .

3- 53.9\% of the respondents have low and moderate environmental congnitive levels .

4- There is a significant correlation between the environmental congnitive level and two independent variables i.e. educational level, attitudes levels. 